\title{
PENCANTUMAN BANKERS CLAUSE DALAM PERJANJIAN KREDIT
}

\author{
Rahmawati Kusuma \\ Fakultas Hukum,Universitas Mataram \\ Lombok, NTB, Indonesia \\ Email:rahmawk@yahoo.com
}

\begin{abstract}
Abstrak
Pemberian pinjaman kepada nasabah atau yang sering dikenal dengan istilah kredit dalam kegiatan perbankan merupakan kegiatan usaha yang paling utama, hal ini dikarenakan pendapatan terbesar dari usaha bank berasal dari pendapatan usaha kredit yang dapat berupa bunga, provisi dan jasa bank lainnya. Namun pada sisi tertentu tidak jarang juga sering terjadi apa yang di sebut dengan istilah kredit macet. Faktor-faktor yang mempengaruhi terjadinya kredit macet ini selain berasal dari nasabah, dapat juga berasal dari bank, karena bank tidak terlepas dari kelemahan yang dimilikinya. Oleh karena itu, sebagai upaya untuk melakukan peluncuran kredit dengan didasari pada upaya mencegah terjadinya kredit bermasalah di kemudian hari, bank mewajibkan nasabah untuk mengasuransikan barang jaminan yang menjadi agunan dalam perjanjian kredit untuk kepentingan pihak bank .
\end{abstract}

\section{Kata Kunci : Asuransi Jaminan; Perjanjian Kredit}

\begin{abstract}
Lending to customers or often known as credit in banking activities is the most important business activity, this is because the biggest income from bank business comes from credit business income which can be in the form of interest, provision and other bank services. But on a certain side it is not uncommon that what is often referred to as bad credit is also common. The factors that influence the occurrence of non-performing loans, besides originating from customers, can also come from banks, because banks are inseparable from their weaknesses. Therefore, in an effort to launch a credit based on efforts to prevent future non-performing loans, the bank requires customers to insure collateral as collateral in the loan agreement for the bank's benefit.
\end{abstract}

\section{Keywords: collateral insurance; credit guarantees}

\section{A. PENDAHULUAN}

Salah satu sarana yang mempunyai peran strategis dalam menserasikan dan menseimbangkan masing-masing unsur dari trilogi pembangunan adalah perbankan. Peran strategis tersebut terutama disebabkan oleh fungsi utama bank sebagai suatu wahana yang dapat menghimpun dan menyalurkan dana masyarkat secara efektif dan efesien, yang dengan berasaskan demokrasi ekonomi mendukung pelaksanaannya pembangunan nasional dalam rangka meningkatkan pemerataan pembangunan dan hasil-hasilnya, pertumbuhan ekonomi dan stabilitas nasional kearah peningkatan taraf hidup rakyat banyak. ${ }^{1}$

Bank sebagai agen pembangunan (agent of development), yakni sebagai lembaga yang bertujuan guna mendukung pelaksanaan pembangunan nasional. Sebagai institusi dan agen pembangunan, keberadaan dunia perbankan diharapkan dapat berperan ditengah-tengah kehidupan ini dengan baik. Adanya peranan yang demikian membawa konsekuensi bahwa perbankan nasional dituntut untuk selalu dapat memberikan manfaat yang sebesar-besarnya guna meningkatkan pertumbuhan ekonomi, sehingga tercipta stabilitas nasional yang mengarah pada peningkatan kesejahteraan rakyat banyak.

${ }^{1}$ Muhammad Dujumhana.(2003). Hukum Perbankan Di Indonesia. Bandung: Citra Aditya Bakti, hlm. 548-549. 
Memperhatikan peranan lembaga perbankan yang demikian strategis dalam mencapai tujuan pembangunan nasional, maka terhadap lembaga perbankan perlu senantiasa terdapat pembinaan dan pengawasan yang efektif, dengan didasari oleh landasan gerak yang kokoh agar lembaga perbankan di Indonesia mampu berfungsi secara efisien, sehat, wajar, dan mampu menghadapi persaingan yang semakin bersifat global, mampu melindungi secara baik dana yang dititipkan masyarakat kepadanya, serta mampu menyalurkan dana masyarakat tersebut ke bidang-bidang yang produktif bagi pencapaian sasaran pembangunan.

Dengan meningkatnya kebutuhan akan jasa perbankan yang telah berkembang pesat, maka landasan gerak perbankan yang ada dirasakan sudah saatnya diadakan penyesuaian agar mampu menampung tuntutan pengembangan jasa perbankan.

Pemberian pinjaman kepada nasabah atau yang sering dikenal dengan istilah kredit dalam kegiatan perbankan merupakan kegiatan usaha yang paling utama, hal ini dikarenakan pendapatan terbesar dari usaha bank berasal dari pendapatan usaha kredit yang dapat berupa bunga, provisi dan jasa bank lainnya.

Dari manfaat nyata yang diharapkan maka sekarang ini kredit dalam kehidupan perekonomian dan perdagangan memiliki fungsi :2

1. Meningkatkan daya guna uang;

2. Meningkatkan peredaran dan lalu lintas uang;

3. Meningkatkan daya guna dan peredaran barang;

4. Salah satu alat stabilitas ekonomi;

5. Meningkatkan kegairahan berusaha;

6. Meningkatkan pemerataan pendapatan;

7. Meningkatkan hubungan internasional.

Namun pada sisi tertentu tidak jarang juga sering terjadi apa yang di sebut dengan istilah kredit macet.

Faktor-faktor yang mempengaruhi terjadinya kredit macet ini selain berasal dari nasabah, dapat juga berasal dari bank, karena bank tidak terlepas dari kelemahan yang dimilikinya. Faktor ini tidak berdiri sendiri tetapi selalu berkaitan erat dengan nasabah. ${ }^{3}$ Oleh karena itu, sebagai upaya untuk melakukan peluncuran kredit dengan didasari pada upaya mencegah terjadinya kredit bermasalah di kemudian hari, maka berdasarkan ketentuan Pasal 2 UU Nomor 10 Tahun 1998 Tentang Perbankan menentukan bahwa kegiatan bank dilaksanakan bersasakan prinsip kehati-hatian (prudential banking) sebagai salah satu upaya untuk menghindari terjadinya kredit macet. Untuk itu sebelum suatu permohonan kredit disetuji, maka terlebih dahulu dilakukan penilaian dengan berpedoman formula $5 \mathrm{C}$ yaitu $:^{4}$
1. Character
2. Capasity
3. Capital
4. Collateral
5. Condition of economy

${ }^{3}$ Gatot Supramono.(1996). Perbankan dan Masalah Kredit Suatu Tinjauan Yuridis. Jakarta: Djembatan, hlm. 132

${ }^{4}$ Hermansyah, Op.Cit . hlm. 63 
Disamping itu, bahwa dalam upaya lebih menjamin kepastian hukum terhadap kredit yang disalurkan, bank mewajibkan nasabah untuk mengasuransikan obyek jaminan yang menjadi agunan dalam perjanjian kredit untuk kepentingan pihak bank .

Hal ini misalnya tercermin dalam salah satu pasal perjanjian kredit pada PT. Bank Danamon Mataram ${ }^{5}$ )

Pasal 10 ayat (1) tentang Asuransi Barang Jaminan :

"Debitur atas tanggungan sendiri harus selalu mengasuransikan harta benda yang dijaminkan oleh debitur dan/atau penjamin kepada Bank pada perusahaan asuransi dan sampai jumlah pertanggungan yang ditetapkan oleh Bank, terhadap kerugian karena kebakaran, dan bahaya-bahaya lain yang menurut pertimbangan Bank dapat menimpa harta benda tersebut"

"Setiap polis asuransi harus memuat Banker's Clause, yakni bahwa selama harta benda yang diasuransikan masih merupakan jaminan hutang kepada Bank, maka uang pertanggungan yang dibayar oleh perusahaan asuransi akan diserahkan langsung oleh perusahaan asuransi tersebut kepada Bank dan selanjutnya untuk diperhitungkan dengan hutang debitur kepada Bank dan jika masih ada sisa, menyerahkan sisa tersebut kepada Debitur atau Penjamin sebagai pemilik harta benda yang dijaminkan kepada Bank"

Oleh karena itu penelitian ini menjadi menarik untuk dilakukan, karena meskipun melalui instrumen pengikatan/pembebanan jaminan baik melalui fidusia maupun hak tanggungan secara yuridis normatif telah memberi hak prevellege kepada kreditur terhadap obyek jaminan apabila debitur wanprestasi, namun dalam praktek perbankan pihak debitur diwajibkan juga untuk mengasuransikan obyek jaminan dalam perjanjian kredit untuk kepentingan kreditur. Atas dasar berbagai argumentasi tersebut, maka menarik untuk dilakukan kajian secara yuridis normatif terhadap beberapa isu hukum yaitu : (1). Apakah yang melatarblakangi adanya kewajiban bagi pihak debitur untuk mengasuransikan obyek jaminan dalam perjanjian kredit?, (2). Bagaimanakah perlindungan hukum terhadap pihak debitur dalam perjanjian asuransi obyek jaminan perjanjian kredit?

\section{B. METODE PENELITIAN}

Jenis penelitian yang akan digunakan pada penelitian ini adalah penelitian normatif dengan mengkaji literatur-literatur yang ada dan Peraturan Perundang-undangan yang berkaitan dengan permasalahan yang akan diteliti. Adapun metode pendekatan yang digunakan dalam penelitian ini adalah : Pendektan Undang-undang (Statute Approach) dan Pendekatan konseptual (Conceptual Approach),Metode analisis yang digunakan adalah deskriptif kualitatif

\section{PEMBAHASAN}

\section{Kewajiban untuk mengasuransi Obyek Jaminan Dalam Perjanjian Kredit}

Dalam pemberian kredit, khususnya kredit bank biasanya diawali dengan suatu perjanjian yang disebut dengan perjanjian kredit dan umumnya dilakukan dalam bentuk tertulis. Oleh karena itu, sesuai dengan ketentuan dalam Pasal 1338 ayat 1 KUH Perdata, maka seluruh Pasal-pasal yang ada dalam suatu perjanjian kredit secara umum mengikat kedua belah pihak, yakni pihak Kreditur dan pihak Debitur. Asal saja tidak ada Pasal-pasal yang bertentangan dengan hukum yang berlaku. Keterikatan yang sama juga berlaku bagi perjanjian-perjanjian

\footnotetext{
${ }^{5}$ Akte Perjanjian Perubahan dan terhadap Perpanjangan Kredit antara PT Bank Danamon Mataram Tbk sebagai Pihak Pertama dengan Ratna Trisna Widjaja sebagai Pihak kedua. Akta No. 114 tertanggal 18-5-2010 yang dibuat oleh dan dihadapan Notaris/ PPAT I Gede Sutama, SH
} 
pendukung lain seperti perjanjian jaminan hutang, teknik pelaksanaan pembayaran atau pembayaran kembali, atau lain-lainnya yang biasanya merupakan exibit atau lampiran dari perjanjian kredit yang bersangkutan. ${ }^{6}$

Dalam hal yang sama, juga dapat dijelaskan sekitar klausul-klausul perjanjian kredit pada Bank yang menguraikan tentang beberapa fungsi perjanjian kredit, diantaranya yaitu : ${ }^{7}$

1. Perjanjian Kredit berfungsi sebagai perjanjian pokok, artinya perjanjian kredit merupakan sesuatu yang menentukan batal atau tidak batalnya perjanjian lain yang mengikutinya, misalnya perjanjian pengikatan jaminan.

2. Perjanjian kredit berfungsi sebagai alat bukti mengenai batasan-batasan hak dan kewajiban di antara kreditur dan debitur.

3. Perjanjian kredit berfungsi sebagai alat untuk melakukan monitoring kredit.

Perjanjian kredit (PK) sepenuhnya menurut Hukum Perdata Indonesia, merupakan salah satu dari bentuk perjanjian pinjam-meminjam yang di atur dalam Buku ke Tiga KUH Perdata. Dalam bentuk apapun juga pemberian kredit itu diadakan pada hakekatnya merupakan salah satu perjanjian pinjam-meminjam sebagaimana diatur dalam Pasal 1754 s/d 1769 KUH Perdata.

Namun demikian dalam praktek perbankan modern, hubungan hukum dalam kredit tidak lagi semata-mata berbentuk hanya perjanjian pinjam-meminjam saja, melainkan adanya campuran dalam bentuk perjanjian lain seperti, perjanjian pemberian kuasa. Dalam bentuk yang campuran demikian, maka selalu tampil bentuk dari suatu hubungan atau jalinan diantara perjanjian yang terkait tersebut. Dalam praktek perbankan pada dasarnya bentuk dan pelaksanaan suatu perjanjian pinjam-meminjam yang ada dalam KUH Perdata tidaklah sepenuhnya identik dengan bentuk dan pelaksanaan suatu perjanjian kredit perbankan, diantara keduanya terdapat perbedaan-perbedaan yang gradual atau bahkan dapat pula merupakan perbedaan yang Pokok. ${ }^{8}$

Dalam praktek bentuk dan materi perjanjian kredit antara satu bank dengan Bank yang lain tidaklah sama, hal ini terjadi dalam rangka menyesuaikan diri dengan kebutuhanya masing-masing. Dengan demikian perjanjian kredit tersebut tidak mempunyai bentuk yang berlaku umum, hanya saja dalam praktek ada banyak hal yang biasanya dicantumkan dalam perjanjian kredit berupa definisi dan istilah-istilah yang akan dipakai dalam perjanjian, (ini terutama dalam hal perjanjian kredit dengan pihak asing atau yang dikenal dengan istilah Loan Agreement), jumlah dan batas waktu pinjaman serta pembayaran kembali pinjaman (repayment) juga mengenai apakah si Peminjam berhak mengembalikan dana pinjaman lebih cepat dari ketentuan yang ada, penetapan bunga pinjaman dan dendanya bila debitur lalai dalam membayar bunga, dan yang terahir dicantumkan berbagai klausul seperti hukum yang berlaku untuk perjanjian tersebut. ${ }^{9}$

Perikatan yang lahir karena perjanjian harus dapat mengikat, yaitu menimbulkan kewajiban dan hak dari adanya perikatan tersebut serta perjanjian itu dapat dipaksakan secara hukum. ${ }^{10}$ Bila salah satu pihak tidak melaksanakan kewajibannya sebagaimana yang diperjanjikan maka pihak yang lain dapat menuntut melalui pengadilan. Agar debitur memenuhi kewajibannya atau menggantikan ganti rugi dan bunga. Salah satu pihak dianggap tidak memenuhi kewajibannya atau melakukan Wanprestasi, bila : ${ }^{11}$

1. Tidak melakukan apa yang telah disanggupi untuk dilakukannya, atau

\footnotetext{
${ }^{6}$ Munir Fuady.(1996). Hukum Perkreditan Kontemporer. Bandung: PT.Citra Aditya Bakti, hlm. 8

${ }^{7}$ Muhammad Djumhana.(2000). Hukum Perbankan di Indonesia. Bandung: PT. Citra Aditya Bakti, hlm.338

${ }^{8}$ Ibid., hlm. 385-386

${ }^{9}$ Ibid., hlm. 386-387

${ }^{10}$ Subekti.(1992). Hukum Perjanjian. Bandung: Intermasa, hlm. 45

${ }^{11}$ Ibid., hlm. 45
} 
2. Melaksanakan apa yang diperjanjikan tetapi tidak sebagaimana mestinya, atau

3. Melaksanakan apa yang dijanjikan tetapi terlambat, atau

4. Melakukan sesuatu yang menurut perjanjian tidak boleh dilakukan.

Untuk menentukan seseorang tersebut Wanprestasi maka perlu diperhatikan yaitu : Jika pada waktu jatuh temponya tanggal perjanjian, tindakan melunasi atau mengangsur pinjaman tidak dipenuhi, dengan sendirinya peminjam telah cedera janji dan dalam hal administrasi ia akan dimasukkan sebagai penunggak. ${ }^{12}$ Terhadap kelalaian atau kealfaan si berhutang itu (si berhutang atau debitur adalah pihak yang wajib melakukan sesuatu), di ancam dengan beberapa sanksi atau hukuman.

Hukuman atau sanksi bagi debitur yang lalai itu terdiri dari empat macam, yaitu : ${ }^{13}$

1. Membayar kerugian yang di derita oleh Kreditur atau dengan singkat dinamakan Ganti rugi.

2. Pembatalan perjanjian atau juga dinamakan "pemecahan" Perjanjian.

3. Peralihan Resiko, dan

4. Membayar biaya perkara, apabila diperkarakan di muka Hakim.

Mengenai perjanjian-perjanjian untuk menyerahkan suatu barang atau untuk berhutang akan dianggap lalai dengan lewatnya waktu yang ditentukan, pelaksanaan prestasi ini harus lebih dulu ditagih. Kepada debitur itu harus diperingatkan bahwa kreditur menghendaki pelaksanaan perjanjian. Kalau prestasi dapat seketika dilakukan, misalnya dalam jual-beli suatu barang tertentu yang sudah ditangannya si penjual, maka prestasi tadi tentunya dapat dituntut seketika (dalam hal ini menyerahkan barang tersebut). Apabila prestasi tidak seketika dapat dilakukan, maka si berhutang perlu di berikan waktu yang pantas. Misalnya dalam jual-beli barang yang belum berada ditangannya si penjual, pembayaran kembali uang pinjaman, dan lain sebagainya. ${ }^{14}$ Tentang bagaimana cara kreditur memberikan peringatan terhadap debitur, "Apabila debitur itu tidak memenuhi teguran yang dihadapkan kepadanya, maka dapat dikatakan bahwa debitur itu telah lalai". Petunjuk yang terdapat dalam Pasal 1238 Kitab Undang-Undang Hukum Perdata, yang berbunyi :

"Si Berhutang adalah lalai, bila ia dengan surat perintah atau dengan sebuah Akta sejenis itu telah dinyatakan lalai, atau demi perikatannya sendiri jika ini menetapkan bahwa siberhutang akan harus dianggap lalai dengan lewatnya waktu yang ditentukan”

Apabila seorang debitur sudah diperingatkan atau sudah dengan tegas ditagih janjinya, seperti yang diterangkan di atas, maka jika ia tetap tidak melakukan prestasinya, ia berada dalam keadaan lalai, alfa dan terhadapnya dapat diperlakukan sanksi-sanksi sebagaimana disebutkan di atas, yaitu ganti-rugi.

Bentuk penjanjian yang biasanya digunakan oleh bank ada 2 (dua) macam yaitu :

a. Di bawah tangan (Onderhandsacte)

Dalam praktek bentuk perjanjian ini dinamakan perjanjian standar atau baku. Maksudnya ialah bahwa perjanjian yang isinya sudah dibakukan atau sudah dalam bentuk tertulis dan dibuat oleh pihak yang kuat yaitu pihak kreditur. Menurut Pasal 1874 KUHPerdata perjanjian di bawah tangan adalah setiap akte yang tidak dibuat oleh atau dihadapan seorang pejabat/pegawai umum. Biasanya bentuk perjanjian ini diberlakukan

\footnotetext{
${ }^{12}$ R. Tjipto Nugroh. Perbankan Masalah Perkreditan. Jakarta: Pradiya Paramita, hlm. 137

${ }^{13}$ Agnes. M. Togar.(1987). Kursus Hukum Perikatan Hukum Perjanjian. Dewan Kerjasama Ilmu Hukum Belanda Dengan Indonesia Proyek Hukum Perdata. Yogyakarta, hlm. 43

${ }^{14}$ Ibid., hlm. 44
} 
kepada debitur perseorangan. Berkaitan dengan itu, memang dalam prakteknya bentuk perjanjian telah disediakan oleh pihak PT Bank Danamond sebagai kredtur, sedangkan debitur hanya mempelajarinya dan memahaminya dengan baik. Sehingga perjanjian ini dianggap sebagai perjanjian baku (standard contract), dimana dalam perjanjian tersebut pihak debitur hanya dalam posisi menerima atau menolak tanpa ada kemungkinan untuk melakukan negosiasi atau tawar menawar. ${ }^{15}$

Berdasarkan ketentuanini, apabila debiturmenerima semua ketentuan dan persyaratan yang ditentukan oleh PT Bank Danamond, maka dia berkewajiban untuk menandatangani perjanjiankredittersebut,tetapiapabiladebiturmenolakiatidakperluuntukmenandatangani kredit tersebut.

b. Dibuat Notariil / Akte Authentik

Dalam hal ini kedua belah pihak yaitu debitur dan kreditur membuat persetujuan atau kesepakatan di hadapan Notaris. Menurut Pasal 1868 KUHPerdata, Akte Authentik adalah suatu akte yang dalam bentuk sebagaimana ditentukan olehUndang-undang, dibuat oleh atau dihadapi pegawai yang berwenang untuk itu ditempat mana akte dibuat. Menurut Undang-undang suatu akte authentik mempunyai kekuatan pembuktian yang sempurna (volleding bewijs), artinya apabila suatu pihak memajukan suatu akte authentik, hakim harus menerimanya dan menganggap apa yang dituliskan dalam akte tersebut sungguhsungguh telah terjadi, hingga hakim tidak boleh memerintahkan tambahan pembuktian lagi. ${ }^{16}$

Dalam dunia perbankan, bank tidak menentukan secara khusus surat perjanjian mana yang digunakan apakah di bawah tangan atau dibuat Notariil dalam perjanjian kredit, tetapi biasanya ditentukan oleh besar kecilnya jumlah kredit. Apabila jumlah kredit besar biasanya surat perjanjian dibuat notariil, tetapi jika jumlah kredit kecil biasanya surat perjanjian dibuat di bawah tangan.

Praktinya, isi atau materi setiap perjanjian adalah berbeda, tetapi dalam menentukan isi perjanjian kredit para pihak harus mengadakan kesepakatan yang nantinya tertuang dalam perjanjian. Berikut ini dijelaskan mengenai isi perjanjian, dalam hal ini diambil sampel perjanjian kredit pada PT. Bank Danamon Indonesia cabang Mataram yang antara lain memuat ketentuan-ketentuan sebagai berikut :

a. Klausul mengenai penggunaan pinjaman

Klausul ini menerangkan secara jelas mengenai keperluan dari pihak yang berhutang.

b. Klausul mengenai penarikan kredit pertama kali

c. Klausul mengenai syarat-syarat penarikan pinjaman. Persyaratan penarikan pinjaman ditentukan menurut kebijakan bank.

d. Dalam jaminan harus dijelaskan secara terperinci, mengenai jenis jaminan, pengikatan jaminan dan form yang digunakan. Dalam hal ini kredit atau pembiayaan yang di berikan oleh bank harus memperhatikan asas-asas perkreditan sesuai dengan prinsip syariah yang sehat. Untuk mengurangi resiko tersebut, jaminan pemberian kredit atau pembiayaan berdasarkan prisip syariah dalam arti keyakinan atas kemampuan dan kesanggupan nasabah debitor untuk melunasi kewajibannya sesuai dengan yang diperjanjikan merupakan hal yang penting yang harus diperhatikan oleh bank. ${ }^{17}$

\footnotetext{
${ }^{15}$ Ibid., hlm. 71

${ }^{16}$ Yan Pramadya Puspa.(1977). Kamus Hukum. Semarang: Aneka Ilmu, hlm.31

${ }^{17}$ Indonesia.Penjelasan Pasal 8 ayat (1) dan (2)Undang-Undang No.10 Tahun 1998 Tentana Perbankan.
} 
Dengan demikian untuk memperoleh keyakinan tersebut, sebelum memberikan kredit, bank harus memberikan penilaian yang saksama terhadap watak, kemampuan, modal, agunan, dan prospek usaha dari nasabah debitor. ${ }^{18}$

e. Asuransi :

f. Klausul mengenai kewajiban tambahan debitur.

g. Klausul mengenai pemeriksaan dan pengawasan. Klausul ini mengatur hak Bank untuk melakukan pemeriksaan kepada debitur.

h. Klausul pernyataan mengenai :

1) Pemberian keterangan yang sebenar-benarnya oleh debitur yang dipergunakan Bank untuk memeriksa penggunaan pinjaman yang dimaksud.

2) Tata cara pembayaran apabila pinjaman ternyata menyimpang dari tujuan semula.

3) Mengatur tata cara eksekusi seluruh jaminan apabila pinjaman tidak dilunasi pada waktu yang telah ditentukan.

i. Klausul mengenai biaya tambahan, biaya tersebut meliputi : bea materai, biaya percetakan, biaya notaris, biaya Pejabat Pembuat Akte Tanah (PPAT) dan biaya lainnya.

j. Klausul domisili

Klausul ini menerangkan tempat kedudukan hukum yang tetap. Penentuan domisili sebagai bentuk kepastian hukum apabila di kemudian hari pemberian kredit bermasalah.

k. Ketentuan tambahan :

1) Mengatur hak-hak terhadap kuasa debitur.

2) Diluar ketentuan pokok, Bank dapat mengatur lebih lanjut mengenai segala sesuatu yang belum diatur dalam perjanjian.

3) Persetujuan debitur terhadap syarat-syarat umum perjanjian pinjaman dan kredit PT Bank Danamond.

4) Ketentuan pemberlakuan perjanjian sejak penandatanganan perjanjian kredit.

Disadari bahwa Kredit yang diberikan oleh bank mengandung resiko, sehingga dalam pelaksanaannya, bank harus memperhatikan azas-azas perkreditan. Untuk mengurangi resiko tersebut, jaminan pemberian kredit dalam arti keyakinan atas kemampuan dan kesanggupan nasabah debitur untuk melunasi kewajibannya sesuai dengan yang diperjanjikan merupakan faktor penting yang harus diperhatikan oleh bank.

Untuk memperoleh keyakinan tersebut, sebelum memberikan kredit, bank harus melakukan penilaian yang seksama terhadap watak, kemampuan, modal, agunan, dan prospek usaha dari nasabah debitur. ${ }^{19}$ Untuk menganalisis suatu permohonan kredit pada umumnya digunakan kriteria $5 \mathrm{C}$ atau The Five $C$ 's yakni : ${ }^{20}$

\section{Character (sifat)}

Dalam hal ini, para analist kredit pada umumnya mencoba melihat dari data pemohon kredit yang telah disediakan oleh bank. Bila dirasakan perlu diadakan wawancara, untuk mengetahui lebih rinci, bagaimana karakter yang sesungguhnya dari calon debitur tersebut.

\section{Capasity (kemampuan)}

\footnotetext{
${ }^{18}$ Hermansyah, Hukum Perbankan Naional Indonesia. Op. Cit. hlm. 73

${ }^{19}$ Penjelasan Pasal 8 ayat 1 Undang-Undang Nomor 7 Tahun 1992 tentang Perbankan sebagaimana telah diubah dengan Undang-Undang Nomor 10 Tahun 1998 tentang Perubahan atas Undang-Undang Nomor 7 Tahun 1992 tentang Perbankan

${ }^{20}$ Sentosa Sembiring.(2000). Hukum Perbankan. Bandung: Mandar Maju, hlm. 68-69
} 
Bank mencoba menganalisis apakah permohonan dana yang diajukan rasional atau tidak dengan kemampuan yang ada pada debitur sendiri. Bank melihat sumber pendapatan dari pemohon dikaitkan dengan kebutuhan hidup sehari-hari.

\section{Capital (modal)}

Hal ini cukup penting bagi bank, khususnya untuk kredit yang cukup besar apakah dengan modal yang ada, mungkin pengembalian kredit yang diberikan. Untuk itu perlu dikaji ulang potensi dari modal yang ada.

4. Collateral (jaminan)

Apakah jaminan yang diberikan oleh debitur sebanding dengan kredit yang diminta. Hal ini penting agar bila debitur tidak mampu melunasi kreditnya, jaminan dapat dijual.

\section{Condition of Economy (kondisi ekonomi)}

Situasi dan kondisi ekonomi apakah memungkinkan untuk itu.

Dalam ketentuan Pasal 8 ayat 2 Undang-Undang Nomor 10 Tahun 1998 tentang Perubahan atas Undang-Undang Nomor 7 Tahun 1992 tentang Perbankan menyatakan bahwa Bank Umum wajib memiliki dan menerapkan pedoman perkreditan dan pembiayaan berdasarkan prinsip syariah, sesuai dengan ketentuan yang ditetapkan oleh Bank Indonesia. Pokok-Pokok ketentuan yang ditetapkan oleh Bank Indonesia memuat antara lain :

1. Pemberian kredit atau pembiayaan berdasarkan prinsip syariah dibuat dalam bentuk perjanjian tertulis;

1. Bank harus memiliki keyakinan atas kemampuan dan kesanggupan nasabah debitur yang antara lain diperoleh dari penilaian yang seksama terhadap watak, kemampuan, modal, agunan dan prospek usaha dari nasabah debitur;

2. Kewajiban bank untuk menyusun dan menerapkan prosedur pemberian kredit atau pembiayaan berdasarkan prinsip syariah;

3. Kewajiban bank memberikan informasi yang jelas mengenai prosedur dan persyaratan kredit atau pembiayaan berdasarkan prinsip syariah;

4. Larangan bank untuk memberikan kredit atau pembiayaan berdasarkan prinsip syariah dengan persyaratan yang berbeda kepada nasabah debitur atau pihak-pihak yang terafiliasi;

5. Penyelesaian sengketa.

Berdasarkan uraian tersebut diatas, maka telah jelas diatur dalam Undang-Undang Perbankan mengenai kewajiban bank untuk memiliki keyakinan berdasarkan analisis yang mendalam atau iktikad baik dan kemampuan serta kesanggupan nasabah debitur untuk melunasi utangnya sesuai dengan yang diperjanjikan atau dengan kata lain, bank wajib menerapkan prinsip kehati-hatian sebelum memutuskan untuk menerima permohonan kredit dari nasabah debitur.

Dengan demikian jika mengacu pada substansi perjanjian kredit, maka adanya kewajiban untuk mengasuransikan obyek jaminan disamping untuk kepentingan ekonomi (terutama berkurangnya nilai obyek jaminan, baik karena penyusutan secara alamiah maupun karena faktor peristiwa alam yang menimpa obyek jaminan) juga dimaksudkan sebagai perlindungan secara yuridis (kreditur prevellege).

Dalam praktek, bentuk dan isi perjanjian kredit antara satu Bank dengan Bank yang lain berbeda, hal ini terjadi dalam rangka untuk menyesuaikan diri dengan kebutuhannya masingmasing. Dalam hal ini Bank Danamon telah menyiapkan blanko permohonan dan persyaratan 
dalam bentuk formulir kosong untuk selanjutnya diisi oleh setiap debitur sebagai pemohon kredit. Hal ini dimaksudkan oleh lembaga perbankan untuk mempermudah calon nasabah untuk mengisi hal-hal yang tercantum dalam blanko tersebut. ${ }^{21}$

Pada Bank Danamon Mataram, sebelum perjanjian ditandatangani oleh kedua belah pihak, calon debitur harus melalui beberapa tahap yang meliputi :
a. Surat pengakuan hutang;
b. Copy KTP atau bukti diri lainnya;
c. Laporan pemeriksaan di lapangan
d. Asli bukti kepemilikan agunan;
e. Laporan penilaian agunan;
f. Surat penyerahan dokumen penting;
g. Dokumen pengikatan agunan;
h. Asli surat kuasa pencairan deposito atau tabungan;
i. Asli print out SL pinjaman lunas 3 tahun terakhir.

Salah satu klausul yang terkait dengan jaminan adalah adanya kewajiban DEBITUR atas tanggungan sendiri harus selalu mengansuransikan harta benda yang dijaminkan oleh DEBITUR dan/atau penjamian kepada BANK pada perusahan asuransi dan sampai jumlah pertanggungan yang di tetapkan oleh BANK, terhadap kerugian terhadap kebakaran dan bahaya-bahaya lain pada yang menurut pertimbangan BANK dapat menimpa harta benda tersebut.

Setiap polis asuransi harus membuat 'Banker's Clause” yakni bahwa selama harta benda yang di asuransikan masih merupakan jaminan hutang kepada BANK maka uang pertanggungan yang dibayar oleh perusahaan asuransi akan diserahkan langsung oleh perusahaan asuransi tersebut kepada BANK dan selanjutnya untuk diperhitungkan dengan hutang DEBITUR kepada BANK, dan jika masih ada sisa menyerahkan sisa tersebut kepada DEBITUR atau PENJAMIN sebagai pemilik harta benda yang dijaminkan kepada BANK.

Dalam hal hasil uang pertanggungan tidak cukup untuk melunasi seluruh hutang sisa hutang tersebut tetap menjadi hutang DEBITUR kepada BANK dan harus dibayar dengan seketika dan sekaligus oleh DEBITUR pada saat ditagih oleh BANK. Asli kuitansi atau bukti pembayaran premi asuransi dan asli polis asuransi beserta "Banker" Clause" harus diserahkan kepada BANK.

Jika menurut pertimbangan BANK DEBITUR, lalai memenuhi kewajiban sebagaimana ayat 9.1 maka tanpa mengurangi kewajiban DEBITUR tersebut BANK berhak dan dengan ini diberikan kuasa oleh DEBITUR untuk dan atas tanggunganya .

DEBITUR mengansuransikan harta benda yang dijaminkan dan mendebet rekening DEBITUR pada BANK sejumlah premi asuransi serta biaya-biaya lain yang harus dibayar, tetapi hal tersebut bukan merupakan kewajiban BANK.

Apabila DEBITUR karena satu dan lain hal lalai atau tidak melaksanakan haknya pada saat hak tersebut timbul untuk mengajukan klaim kepada perusahaan asuransi sebagai mana dimaksud dalam ayat 10.1 maka BANK atas tanggungan DEBITUR dengan ini diberi kuasa oleh DEBITUR untuk melakukan klaim kepada perusahaan asuransi untuk dan atas nama DEBITUR dan melaksanakan sesuatu yang diperlukan itu termasuk tetapi tidak terbatas pada pengurusan surat-surat/dokumen-dokumen yang berhubungan dengan pengajuan klaim tersebut kepada perusahaan asuransi serta DEBITUR wajib menyerahkan segala dokumen

\footnotetext{
${ }^{21}$ Salim HS.(2006). Perkembangan hukum Kontrak Di Luar KUH Perdata. Jakarta: PT. Raja Grapindo Persada, hlm. 98
} 
yang diperlukan oleh BANK untuk melaksanakan pengajuan klaim asuransi tersebut, tetapi pengajuan klaim dimaksud di atas bukan kewajiban BANK.

Terkait dengan adanya kewajiban untuk mengasuransikan obyek jaminan kredit untuk kepentingan bank (bankers clause) dalam perjanjian kredit di PT. Bank Danamon telah menimbulkan perselisihan yang berujung pada penyelesaian sengketa di Pengadilan.

Hal tersebut berawal dari adanya penolakan klaim asuransi kebakaran oleh pihak asuransi dengan alasan bahwa jangka waktu asuransinya telah berakhir dan tidak dilakukan perpanjangan masa asuransi.

Klausula bank adalah suatu klausula yang tercantum dalam polis yang hanya dicantumkan atas permintaan Bank di mana dalam polis secara tegas dinyatakan bahwa pihak bank adalah sebagai penerima ganti rugi atas obyek pertanggungan sebagaimana disebutkan dalam perjanjian asuransi (polis). Klausula ini muncul sebagai akibat adanya hubungan hutang piutang antara debitur dan kreditur dimana obyek pertanggungan adalah menjadi jaminan bank, sehingga klausula ini bukan merupakan standard yang pada umumnya tercantum dalam polis (perjanjian asuransi). Oleh karena itu banker's clause hanya dikenal secara khusus dalam dunia perbankan.

Dalam setiap kegiatan usaha termasuk bank tentunya mempunyai resiko sehingga bank mengamankan diri dengan jaminan baik secara yuridis maupun secara fisik. Perusahaan yang mengkhusukan diri dalam mengambil alih resiko atas fisik fisik barang jaminan atau agunan adalah perusahaan asuransi. ${ }^{22}$ Sesuatu yang tidak layak dan tidak patut apabila salah satu pihak telah menerima pemberitahuan tentang batas akhir masa asuransi. namun tidak diteruskan kepada pemilik obyek jaminan yang apabila diketahui lebih awal kemungkinan timbulnya kerugian akibat tidak diperpanjangnya masa asuransi bisa dihindari. Hal ini diperjelas dengan Yurisprudensi Mahkamah Agung Republik Indonesia Nomor: 3431/K/Pdt/1985 tanggal 4 Maret 1987 tentang Bunga Pinjaman Uang dan Barang Jaminan, yang bertentangan dengan kepatutan dan keadilan dan Yurisprudensi Mahkamah Agung Republik Indonesia Nomor: 1904/Sip/1982 ,tanggal 28 Januari 1984 tentang Pembatalan Perikatan; kekuasaan hakim untuk mencampuri isi suatu perjanjian.

Perjanjian kredit yang dilakukan antara PT Danamon Tbk. Dengan Saurdara Trisna sebagai Pihak kedua telah terjadi sengketa yang berkaitan dengan tidak diinformasikan masa habisnya asuransi dengan dalih harus dengan menggunakan kuasa khusus dan merupakan kewajiban bank seperti yang tercantum dalam akte perpanjangan perjanjian kredit sebagai berikut : ${ }^{23}$ )

Pasal 10 ayat (1) tentang Asuransi Barang Jaminan :

"Debitur atas tanggungan sendiri harus selalu mengasuransikan harta benda yang dijaminkan oleh debitur dan/atau penjamin kepada Bank pada perusahaan asuransi dan sampai jumlah pertanggungan yang ditetapkan oleh Bank, terhadap kerugian karena kebakaran, dan bahaya-bahaya lain yang menurut pertimbangan Bank dapat menimpa harta benda tersebut"

"Setiap polis asuransi harus memuat Banker's Clause, yakni bahwa selama harta benda yang diasuransikan masih merupakan jaminan hutang kepada Bank, maka uang pertanggungan yang dibayar oleh perusahaan asuransi akan diserahkan langsung oleh perusahaan asuransi tersebut kepada Bank dan selanjutnya untuk diperhitungkan dengan hutang

${ }^{22}$ Hermansyah.(2013). Hukum perbankan Nasional Indonesia. Jakarta: Kencana Prenada media group, hlm. 8-9

${ }^{23}$ Akte Perjanjian Peubahan dan terhadap Perpanjangan Kredit antara PT Bank Danamon Mataram Tbk sebagai Pihak Pertama dengan Ratna Trisna Widjaja sebagai Pihak kedua. Akta No. 114 tertanggal 18-5-2010 yang dibuat oleh dan dihadapan Notaris/ PPAT I Gede Sutama, SH 
debitur kepada Bank dan jika masih ada sisa, menyerahkan sisa tersebut kepada Debitur atau Penjamin sebagai pemilik harta benda yang dijaminkan kepada Bank"

"Dalam hal hasil uang pertanggungan tidak cukup untuk melunasi seluruh hutang, maka sisa hutang tersebut tetap menjadi hutang debitur kepada Bank dan harus dibayar dengan seketika dan sekaligus oleh debitur pada saat ditagih oleh Bank. Asli kwitansi atau bukti pembayaran harus diserahkan kepada Bank."

Pasal 10 ayat (2) berbunyi:

"jika menurut pertimbangan Bank, DEBITUR lalai memenuhi kewajiban sebagaimana yang dimaksud dalam ayat 9.1, maka tanpa mengurangi kewajiban DEBITUR tersebut berhak dan dengan ini diberi kuasa oleh DEBITUR untuk dan atas nama tanggungan DEBITUR mengasuransikan harta benda yang dijaminkan dan mendebet rekening DEBITUR pada BANK sejumlah premi asuransi serta biaya-biaya lain yang harus dibayar, tetapi hal tersebut bukan merupakan kewajiban bank.

Berdasarkan ketentuan diatas maka dapat diketahui bahwa kewajiban untuk mengasuransikan barang obyek jaminan oleh debitur adalah bagian dari upaya bank selaku kreditur untuk mengamankan kredit yang disalurkan kepada nasabah baik secara fisik (penyusutan nilai obyek jaminan secara ekonomis, baik karena faktor alamiah maupun karena kejadian yang luar biasa/overmacht/keadaan memaksa) maupun secara yuridis (kedudukan sebagai kreditur prevellege/didahulukan).

\section{Perlindungan Hukum Bagi Debitur Dalam Asuransi Obyek Jaminan}

Prinsip-prinsip perlindungan hukum nasabah mengacu pada filosofi pembangunan nasional yaitu pembangunan manusia Indonesia seutuhnya berlandaskan pada falsafah negara Republik Indonesia. Sebagai prinsip hukum, maka dengan sendirinya menempatkan prinsip hukum untuk menjadi rujukan dalam pengaturan perundang-undangan maupun dalam berbagai putusan pengadilan.

Menurut Koesnoe sebagaimana dikutip oleh Khudzaifah Dimyati ${ }^{24}$, terdapat empat butir idea yang menjadi acuan dalam bahan-bahan hukum nasional yang disebut dengan nilai-nilai dasar tata hukum Indonesia sebagaimana ditegaskan dalam Pembukaan UUDNRI: pertama, hukum mempunyai sifat melindungi, artinya yang harus dilindungi adalah segenap bangsa Indonesia dan seluruh tumpah darah. Pokok pikiran ini menyatakan sifat dan isi perlindungan yang ditempatkan dalam rangka persatuan dan harus terwujud untuk segenap rakyat Indonesia.; kedua, negara hendak mewujudkan keadilan sosial bagi seluruh rakyat. Nilai dasar ini memperlihatkan betapa mendasar dan pentingnya nilai dasar ini dalam tata hukum sehingga ditempatkan secara fundamental dan menjadi acuan bagi seluruh aturan hukum; ketiga, prinsip kedaulatan rakyat. Prinsip ini terkandung keyakinan kemungkinan adanya suatu kemauan dari segenap warga yang hidup bersama di dalam masyarakat. Dengan kata lain, adanya kebulatan kemauan diantara segenap warga yang diperoleh melalui jalan permusyawaratan; keempat, Ketuhanan Yang Maha Esa menurut dasar kemanusiaan yang adil dan beradab. Nilai dasar ini mengisyaratkan perintah untuk menghormati agama masing-masing warga. Hukum adalah pernyataan kesusilaan dan moralitas yang tinggi, baik dalam peraturan maupun dalam pelaksanaannya sebagaimana diajarkan agama.

\footnotetext{
${ }^{24}$ Ibid., hlm 213-214
} 
Keempat rechtsidee tersebut merupakan prinsip-prinsip hukum umum yang harus menjadi landasan dalam membuat norma hukum, di samping adanya prinsip hukum khusus sesuai dengan bidang hukum masing-masing.

Prinsip-prinsip hukum perlindungan nasabah termasuk dalam ruang lingkup hukum ekonomi. Menurut Sri Rejeki Hartono, kajian pengaturan kegiatan ekonomi diakomodasi oleh hukum ekonomi yang meliputi dua ranah hukum yaitu hukum publik dan hukum privat. Ranah hukum publik merupakan wilayah wewenang negara, negara memasuki ranah pubik dalam berbagai campur tangan dalam rangka menjaga keseimbangan kepentingan dalam masyarakat. Oleh karena itu, hukum publik sifatnya mengatur dan memaksa. Sementara itu, ranah hukum perdata merupakan ranah pribadi pada subyek hukum yang saling melakukan interaksi dan transaksi, jadi sifatnya hanya mengatur saja ${ }^{25}$.

Ranah hukum publik berawal dari kebijakan ekonomi sampai pada fungsi pengaturan yang sifatnya memaksa. Ranah publik dikuasai prinsip-prinsip yang sifatnya melindungi kepentingan umum dengan menjaga prinsip keseimbangan dalam rangka menjaga harmonisasi kehidupan masyarakat. Semua perundangan bertujuan untuk kepentingan publik. Sementara ranah hukum perdata adalah ranah hukum yang sifatnya mengatur dengan tujuan memberi peluang kepada para pihak untuk mengatur hubungan hukumnya secara mandiri sepanjang tidak melanggar undang-undang, kesusilaan, dan ketertiban umum.

Prinsip-prinsip tersebut merupakan prinsip yang mendasari norma hukum perlindungan nasabah dalam arti bahwa prinsip-prinsip tersebut menjadi nilai landasan pembentukan peraturan perlindungan nasabah. Perlindungan ini diwujudkan dalam seluruh proses hubungan hukum antara nasabah dengan bank sebelum transaksi, saat transaksi dan pasca-transaksi.

Hak merupakan kepentingan yang dilindungi oleh hukum, sedangkan kepentingan adalah tuntutan yang diharapkan untuk dipenuhi. Kepentingan pada hakikatnya mengandung kekuasaan yang dijamin dan dilindungi oleh hukum dalam melaksanakannya. ${ }^{26}$

Secara tradisional, dikenal dua macam pembedaan hak yaitu hak yang dianggap melekat pada tiap-tiap manusia sebagai manusia dan hak yang ada pada manusia akibat adanya peraturan yaitu hak yang berdasarkan undang-undang ${ }^{27}$. Menurut Janus Sidabalok, hak-hak konsumen terdiri hak konsumen sebagai manusia dan hak konsumen sebagai subyek hukum dan warga negara (bersumber dari undang-undang), dan hak nasabah sebagai pihak-pihak dalam kontrak (dalam hubungan kontrak dengan bank). ${ }^{28}$

Terkait dengan hak-hak nasabah sebagai konsumen, di Indonesia telah ada ketentuan yang mengatur tentang perlindungan konsumen yaitu Undang-Undang Perlindungan Konsumen (UUPK). Adapun UU Perbankan tidak mencantumkan secara khusus ketentuan tentang perlindungan hukum nasabah. UUPK sebagai payung hukum (lex generalis) mengatur materi tentang konsumen, sedangkan UU Perbankan (lex specialis) mengatur nasabah perbankan. Sebagai payung hukum, tidak menutup kemungkinan adanya pengaturan perlindungan nasabah bank secara tersendiri di dalam UU Perbankan mengingat jasa bank memiliki karakteristik yang khusus yang berbeda dengan produk dan jasa dalam UUPK yang bersifat umum.

Demikian juga apabila dikaitkan dengan salah ketentuan yang ada dalam Perjanjian Kredit di PT. Bank Danamon, khususnya dalam Pasal 10 ayat (1) tentang Asuransi Barang Jaminan yang menentukan antara lain :

"Debitur atas tanggungan sendiri harus selalu mengasuransikan harta benda yang dijaminkan oleh debitur dan/atau penjamin kepada Bank pada perusahaan asuransi dan sam-

\footnotetext{
${ }^{25}$ Sri Redjeki Hartono, Op.Cit, hlm. 79-80

${ }^{26}$ Curzon, Loc. Cit.

${ }^{27}$ Theo Huijbers.(1990). Filsafat Hukum. Yogyakarta:Kanisius, hlm. 94-95

${ }^{28}$ Janus Sidabalok.(2006). Hukum Perlindungan Konsumen di Indonesia. Bandung: Citra Aditya Bakti, hlm. 35
} 
pai jumlah pertanggungan yang ditetapkan oleh Bank, terhadap kerugian karena kebakaran, dan bahaya-bahaya lain yang menurut pertimbangan Bank dapat menimpa harta benda tersebut"

"Setiap polis asuransi harus memuat Banker's Clause, yakni bahwa selama harta benda yang diasuransikan masih merupakan jaminan hutang kepada Bank, maka uang pertanggungan yang dibayar oleh perusahaan asuransi akan diserahkan langsung oleh perusahaan asuransi tersebut kepada Bank dan selanjutnya untuk diperhitungkan dengan hutang debitur kepada Bank dan jika masih ada sisa, menyerahkan sisa tersebut kepada Debitur atau Penjamin sebagai pemilik harta benda yang dijaminkan kepada Bank"

"Dalam hal hasil uang pertanggungan tidak cukup untuk melunasi seluruh hutang, maka sisa hutang tersebut tetap menjadi hutang debitur kepada Bank dan harus dibayar dengan seketika dan sekaligus oleh debitur pada saat ditagih oleh Bank. Asli kwitansi atau bukti pembayaran harus diserahkan kepada Bank."

Pasal 10 ayat (2) berbunyi:

"jika menurut pertimbangan Bank, DEBITUR lalai memenuhi kewajiban sebagaimana yang dimaksud dalam ayat 9.1, maka tanpa mengurangi kewajiban DEBITUR tersebut berhak dan dengan ini diberi kuasa oleh DEBITUR untuk dan atas nama tanggungan DEBITUR mengasuransikan harta benda yang dijaminkan dan mendebet rekening DEBITUR pada BANK sejumlah premi asuransi serta biaya-biaya lain yang harus dibayar, tetapi hal tersebut bukan merupakan kewajiban bank.

Berdasarkan ketentuan diatas maka secara umum dapat disimpulkan bahwa :

1. Mengasuransikan obyek jaminan merupakan kewajiban hukum dari debitur;

2. Pembayaran asuransi obyek jaminan dilakukan oleh debitur (melalui pendebetan direkening debitur);

3. Pembayaran klaim asuransi kerugian atas obyek jaminan kredit diberikan terlebih dahulu kepada kreditur;

4. Meskipun bank telah diberi kuasa untuk mengasuransikan dan memperpanjang masa asuransi terhadap obyek jaminan dengan mendebet secara langsung terhadap rekening debitur, tetapi hal ini dianggap bukan sebagai kewajiban hukum dari kreditur.

Dengan demikian menunjukkan bahwa klausul yang menyatakan bahwa mengasuransikan dan memperpanjang masa asuransi obyek jaminan dengan cara mendebet secara langsung pada rekening debitur merupakan klausula yang bersifat eksonerasi (yang membatasi / menghilangkan tanggung jawab), sehingga bertentangan dengan Ketentuan Pasal 18 UU Perlindungan Konsumen dan oleh karenannya dianggap batal demi hukum

Hal ini bersesuaian dengan Ketentuan Pasal 1337 KUHPerdata, yang menentukan bahwa setiap perjanjian yang melanggar undang-undang dinyatakan batal demi hukum. Perjanjian kredit tersebut mengandung klausula baku yang dilarang maka berdasarkan Pasal 18 ayat (3) UUPK dinyatakan bahwa setiap klausula baku yang telah ditetapkan oleh pelaku usaha pada dokumen atau perjanjian yang memenuhi ketentuan sebagaimana dimaksud pada ayat (1) dan ayat (2) dinyatakan batal demi hukum. 
Dalam kaitannya dengan Perjanjian Perpanjangan dan Perubahan Perjanjian Kredit (khususnya terkait dengan perpanjangan masa asuransi atas obyek jaminan), maka dalam hal ini bank telah mengetahui konsekwensi dari tidak diperpanjangnya masa asuransi dari obyek jaminan dan menyatakan bukan kewajiban hukum bank, maka dalam hal ini adanya unsur kesengajaan dari bank untuk tidak memperpanjang masa asuransi atas obyek jaminan. Atas dasar itulah sebagai salah satu bentuk perlindungan hukum terhadap debitur dalam kaitannya dengan asuransi obyek jaminan kredit, maka apabila dengan tidak dilakukannya perpanjangan masa asuransi obyek jaminan oleh kreditur telah menimbulkan kerugian pada debitur, maka pihak debitur dapat mengajukan gugatan kepada kreditur (PT.Bank Danamon) atas dasar telah melakukan Perbuatan Melanggar Hukum (onrechtmatigedaad/ Pasal 1365 KUH Perdata).

\section{KESIMPULAN}

Bahwa dengan adanya kemungkinan menyusut dan berkurangnya nilai ekonomis dari suatu barang baik disebabkan karena faktor alam maupun karena keadaan tertentu (force majeur/overmacht) yang dapat menyebabkan menyusut/berkurangnya nilai ekonomis suatu benda jaminan, maka untuk meminimalisir kerugian yang diderita oleh bank, maka bank mensyaratkan adanya kewajiban untuk mengasuransikan obyek jaminan untuk kepentingan pihak bank (bankers clause) pada pihak nasabah (peminjam) bank. Dengan demikian kewajiban mengasuransikan obyek jaminan untuk kepentingan kreditur oleh debitur adalah bagian dari upaya pihak Bank untuk mengamankan kredit yang telah disalurkan kepada nasabah (debitur) secara yuridis maupun secara fisik.

Bahwa bentuk perlindungan hukum bagi debitiur selaku konsumen dalam asuransi obyek jaminan kredit, adalah Terhadap Hak atas informasi yang benar, jelas, dan jujur mengenai kondisi dan jaminan barang dan /atau jasa; Terhadap Hak untuk memperoleh penyelesaian yang wajar atas sengketa yang dihadapi.

Dengan demikian dalam kaitannya dengan adanya kelalaian Pihak Bank menginformasikan batas akhir masa asuransi suatu obyek jaminan kepada debitur, maka dapat menjadi alasan bagi pihak debitur untuk mengajukan gugatan terhadap bank sebagai salah satu bentuk perlindungan hukum bagi debitur untuk mempertahankan hak keperdataannya yang dirugikan oleh pihak kreditur bahwa pihak bank telah melakukan perbuatan melanggar hukum (Pasal 1365 KUH Perdata) .

\section{DAFTAR PUSTAKA}

\section{Buku}

Muhammad Dujumhana.(2003). Hukum Perbankan Di Indonesia. Bandung: Citra Aditya Bakti.

Gatot Supramono.(1996). Perbankan dan Masalah Kredit Suatu Tinjauan Yuridis. Jakarta: Djembatan.

Munir Fuady.(1996). Hukum Perkreditan Kontemporer. Bandung: PT.Citra Aditya Bakti.

Muhammad Djumhana.(2000). Hukum Perbankan di Indonesia. Bandung: PT. Citra Aditya Bakti.

Subekti.(1992). Hukum Perjanjian. Bandung: Intermasa.

R. Tjipto Nugroh. Perbankan Masalah Perkreditan. Jakarta: Pradiya Paramita.

Agnes. M. Togar.(1987). Kursus Hukum Perikatan Hukum Perjanjian. Dewan Kerjasama Ilmu 
Hukum Belanda Dengan Indonesia Proyek Hukum Perdata. Yogyakarta.

Yan Pramadya Puspa.(1977). Kamus Hukum. Semarang: Aneka Ilmu.

Sentosa Sembiring.(2000). Hukum Perbankan. Bandung: Mandar Maju.

Salim HS.(2006). Perkembangan hukum Kontrak Di Luar KUH Perdata. Jakarta: PT. Raja Grapindo Persada.

Hermansyah.(2013). Hukum perbankan Nasional Indonesia. Jakarta: Kencana Prenada media group.

Theo Huijbers.(1990). Filsafat Hukum. Yogyakarta:Kanisius.

Janus Sidabalok.(2006). Hukum Perlindungan Konsumen di Indonesia. Bandung: Citra Aditya Bakti.

\section{Perundang-Undangan}

Kitab Undang-Undang Hukum Perdata (KHUPerd)

Kitab Undang-Undang Hukum Dagang (KUHD)

Undang-Undang Nomor 2 Tahun 1992, tentang Usaha Perasuransian

Undang-Undang Nomor 40 Tahun 2007 tentang Perseroan Terbatas

Undang-undang Nomor 10 Tahun 1998 Tentang Perbankan

Indonesia.Penjelasan Pasal 8 ayat (1) dan (2)Undang-Undang No.10 Tahun 1998 Tentana Perbankan.

Akta Perjanjian Kredit No. 30 tertanggal 23-06-2008 yang dibuat oleh dan dihadapan Notaris/ PPAT Maudy Margaretha Rarung, SH

Akte Perjanjian Perubahan dan terhadap Perpanjangan Kredit antara PT Bank Danamon Mataram Tbk sebagai Pihak Pertama dengan Ratna Trisna Widjaja sebagai Pihak kedua. Akta No. 114 tertanggal 18-5-2010 yang dibuat oleh dan dihadapan Notaris/ PPAT I Gede Sutama, SH

Penjelasan Pasal 8 ayat 1 Undang-Undang Nomor 7 Tahun 1992 tentang Perbankan sebagaimana telah diubah dengan Undang-Undang Nomor 10 Tahun 1998 tentang Perubahan atas Undang-Undang Nomor 7 Tahun 1992 tentang Perbankan 